\title{
Disease Knowledge and Treatment Adherence among Adult Patients with Thalassemia: A Cross-sectional Correlational Study
}

Wiedza o chorobie i przestrzeganie zaleceń tera peutyczch wśród dorosłych pacjentów z talasemią: przekrojowe badanie korelacyjne

Aisha Alnaami ${ }^{1}$, Dhuha Wazqar ${ }^{2}$

'King Abdulaziz University Hospital ${ }^{2}$ Department of Medical Surgical Nursing, Faculty of Nursing, King Abdulaziz University

Dhuha Wazqar: 0000-0001-6198-653

CORRESPONDING AUTHOR:

Dhuha Wazqar

Department of Medical Surgical Nursing, Faculty of Nursing, King Abdulaziz University P.0. Box 80342, Jeddah 21589 Kingdom of Saudi Arabia Tel: (+966)544555902, Fax: 026400000-20171 e-mail: dwazger@kau.edu.sa

STRESZCZENIE

Słowa kluczowe:

ABSTRACT

Key words:

\section{WIEDZA O CHOROBIE I PRZESTRZEGANIE ZALECEN TERAPEUTYCZCH WŚRÓD DOROSLYCH PACJENTÓW Z TALASEMIA:} PRZEKROJOWE BADANIE KORELACYJNE

Cel. Zbadanie wiedzy na temat choroby i przestrzegania zaleceń terapeutycznych wśród dorosłych pacjentów z talasemią.

Materiał i metody. Przeprowadzono przekrojowe badanie korelacyjne na próbie obejmującej 100 dorosłych pacjentów z talasemią z uniwersyteckiego szpitala w Jeddah. Wykorzystano skalę: Wiedza nt. Talasemii, Skala Przestrzegania Zaleceń Terapeutycznych oraz kwestionariusz z danymi socjodemograficznymi. Dane analizowano przy użyciu pakietu statystycznego dla nauk społecznych w wersji 22. Wykonano statystyki opisowe i wnioskowania oraz korelacje Pearsona.

Wyniki. Uczestnicy mieli umiarkowany poziom wiedzy na temat choroby $(M=15.59, S D=2.30)$ i niski poziom przestrzegania zaleceń terapeutycznych $(M=3.91, S D=1.83)$. Wystąpił również słaby, ale znaczący pozytywny związek między wiedzą na temat choroby a przestrzeganiem zaleceń dotyczących leczenia $(r=0.297, P=0.041)$. Istotną różnicę $w$ średnich punktach przestrzegania zaleceń terapeutycznych stwierdzono wśród uczestników o różnych dochodach miesięcznych $(\mathrm{P}=0.05)$.

Wnioski. Wiedza uzyskana z tego badania może być przydatna w poprawie zrozumienia przez pielęgniarki efektów praktycznej wiedzy na temat przestrzegania zaleceń terapeutycznych. Mogą być wymagane programy edukacyjne/programy interwencji w celu poprawy wiedzy i przestrzegania zaleceń leczenia pacjentów z talasemią. Potrzebne są również badania podłużne, aby przetestować moderatorów i mediatorów relacji wiedzy o chorobie i przestrzegania zaleceń terapeutycznych.

wiedza o chorobie, pielęgniarki, pacjenci z talasemią, Arabia Saudyjska, przestrzeganie zaleceń terapeutycznych

\section{DISEASE KNOWLEDGE AND TREATMENT ADHERENCE AMONG ADULT PATIENTS WITH THALASSEMIA:}

\section{A CROSS-SECTIONAL CORRELATIONAL STUDY}

Aim. To investigate the disease knowledge and treatment adherence among adult patients with thalassemia.

Material and methods. A cross-sectional correlational study was carried out with a convenience sample of 100 adult patients with thalassemia from a university teaching hospital in Jeddah city, Saudi Arabia. The Disease Knowledge about Thalassemia Major, the Treatment Adherence Scale, and sociodemographic survey were completed by participants. The data were analyzed using Statistical Package for the Social Sciences version 22. Descriptive and inferential statistics and Pearson correlations were performed.

Results. The participants had a moderate level of disease knowledge $(M=15.59, S D=2.30)$ and a low level of treatment adherence $(M=3.91, S D=1.83)$. There was also a weak but significant positive relationship between disease knowledge and treatment adherence $(r=0.297, P=0.041)$. A significant difference in treatment adherence mean scores was found among participants with different monthly incomes $(P=0.05)$.

Conclusions. Knowledge gained from this study may be useful in improving nurses' understanding of the effects of providing practical knowledge on treatment adherence. Educational strategies/interventions programs may be required to improve knowledge and adherence to treatment among thalassemia patients. Longitudinal studies are also needed to test for moderators and mediators of relationships of disease knowledge and treatment adherence. 


\section{INTRODUCTION}

Thalassemia (TM) is an inherited blood disease characterized by abnormal hemoglobin production, leading to anemia with high iron accumulations [1]. Treatment for TM patients often includes regular blood transfusion, folic acid, and iron chelation therapy [2]. The ultimate goal of TM management, like any other chronic diseases, is to achieve target control and prevent complications. Thalassemia is a global health problem that is frequently encountered in clinical practice [3]. Annually, around 240 million cases of TM are discovered worldwide, most commonly in the Mediterranean countries and Southeastern Asia [4]. It resulted in 36,000 deaths in 1990 and 16,800 deaths in 2015 due to iron overload in patients with TM [5]. In Saudi Arabia (SA), the estimated prevalence rate of $\beta$-TM major was 0.7 per $1000 ; 12.9$ per 1000 for the trait and 13.6 per 1000 for $\beta$-TM [6]. The important risk factors affecting the occurrence of TM in SA are consanguineous marriage and lack of education programs and school screening [6,7]. Despite the SA's efforts to decrease the occurrence of TM through genetic counseling services and premarital screening programs, the marriage rates among high-risk groups have not significantly reduced [7]. The Saudi Ministry of Health statistics showed that 3000 of the 7500 Saudis who were physically incompatible with TM opted for medical advice and were married [8]. A high percentage of TM patients indicates the need for a comprehensive assessment and interventions to control disease and prevent its complications among this population.

Treatment adherence is crucial to TM control, complications prevention, and therapeutic success [9]. Treatment adherence defined as the extent to which the history of therapeutic drug use by the patient complies with the treatment prescribed [10]. Poor adherence to treatment is a major risk for the development of heart failure, endocrine abnormalities, and stroke among TM patients, and a clear, consistent treatment plan has been shown to help prevent life-threatening complications and extra costs on the healthcare systems $[11,12]$. Pakbaz et al. revealed that TM patients are experiencing low quality of life because of disease complications; which might be overcome with improving knowledge and medical education [13]. Several studies have shown that adequate patient knowledge of TM improves patients' adherence to treatment and improves control of their disease $[14,15,16]$. The hypothesis that the higher level of disease knowledge, the higher level of adherence to treatment was examined in 32 TM patients. The results confirmed this hypothesis: $43 \%$ had inadequate disease knowledge and only $48 \%$ stuck to the treatment [15]. A systematic review conducted by Deborah et al. providing an in-depth examination of theory-guided adherence interventions studies, also suggested that the more information patients receive, the more they adhere to the treatment schedule [17]. Moreover, results from a recent prospective study also indicated that patient knowledge of disease severity was a significant predictor of treatment adherence [12]. While adherence to treatment plan might be affected by many factors such as beliefs, behavioral skills, and family support, the levels of patients' knowledge about their disease seem to be crucial $[9,15,18]$.

Assessment of disease knowledge and treatment adherence is crucial for the patients' improvement and prevent complications. In SA, there is a scarcity of data regarding knowledge and treatment adherence among TM patients. It is hoped that this study will add to the knowledge around TM and will guide the development of strategic interventions to address the issues identified.

\section{AIM}

This study investigated the disease knowledge and treatment adherence among adult patients with TM from a university teaching hospital.

\section{MATERIALS AND METHODS}

The study was conducted after obtaining approval from the Research Ethics Board of King Abdulaziz University Hospital (KAUH), SA (Protocol Reference No. 538-17; dated December 19, 2017).

\section{Study Design and Sample}

This was a cross-sectional correlational study conducted among a convenience sample of adult patients with TM in KAUH, SA. The sample size was calculated based on a power analysis using G-power, with power set at .95 and alpha of .05. All TM patients who met the inclusion criteria in the KAUH were asked to be involved in this study. Inclusion criteria involved the following: (a), age $\geq 18$ years, (b) clinically confirmed TM diagnosis, (c) receive frequent blood transfusion, chelation therapy, and folic acid supplements, (d) no evidence of any serious mental illness or problems, (e) able to communicate with the researchers (understand and speak Arabic or English fluently), and (f) agree to take part in this study.

Sociodemographic data such as age, gender, nationality, marital status, education, and monthly income were collected using a well-designed questionnaire. Informed consent was obtained from the TM patients before data collection.

One hundred and two surveys were distributed to the participants. One hundred were returned and were completed surveys. Consequently, a total number of 100 adult patients with TM provided valid responses for the analysis, representing a response rate of $98 \%$. More than half of the participants were males $(52 \%)$. The mean age of the recruited participants was $24.92(\mathrm{SD}=9.18)$ years. Sixty-two percent of the participants were in age ranged $18-23$ years. Out of the 100 participants, $79 \%$ were single, and only $21 \%$ were married. Furthermore, the majority of the participants were non-Saudi (78\%). Approximately $40 \%$ of the participants had a high school education while only seven percent of them were illiterate. With regards to family monthly income, the results indicated that $79 \%$ of the participants receive less than 5000 SR monthly (Table 1). 
Tab. 1. Sociodemographic characteristics of patients with thalassemia $(n=100)$

\begin{tabular}{|l|c|}
\hline \multicolumn{1}{|c|}{ Variables } & No. (\%) \\
\hline Age (Year) & $24.92(9.18)$ \\
M (SD) & $18-39$ \\
Range & \\
\hline Gender & $52(52)$ \\
Male & $48(48)$ \\
Female & \\
\hline Nationality & $22(22)$ \\
Saudi & $78(78)$ \\
Non-Saudi & \\
\hline Marital status & $79(79)$ \\
Single & $21(21)$ \\
Married & $0(0)$ \\
Divorced/Separated/Widow & \\
\hline Education & $7(7)$ \\
illiterate & $12(12)$ \\
Elementary School & $21(21)$ \\
Intermediate School & $40(40)$ \\
High school & $20(20)$ \\
Bachelor Degree & \\
\hline Monthly income & $79(79)$ \\
< 5000 SR & $15(15)$ \\
5000-10000 SR & $6(6)$ \\
\hline <10000 SR & \\
\hline
\end{tabular}

Note: M, Mean; SD, standard deviation

\section{Instruments}

The Disease Knowledge about Thalassemia Major (DKTM) included 20 items use to assess TM knowledge regarding medical treatment, drug compliance, lifestyle, diet, and complications [15]. Items were scored using zero or one $($ zero $=$ incorrect/one $=$ correct $)$. The DKTM scores ranged from zero to 20 and then calculated to a percentage score from zero to 100 , with lower scores suggesting a poor level of knowledge. The instrument has adequate psychometric properties (Cronbach's alpha $=0.85$ ). The pilot-study TM patients in KAUH stated that it was easy to understand the DKTM. The Cronbach's alpha value for the DKTM in this study was 0.72 .

The Treatment Adherence Scale (TAS) is an eight-item self-report instrument, developed by researchers benefiting from the medication adherence literature, to identify medication-taking behaviors and attitudes related to TM treatment adherence. The TAS includes eight questions that recognize non-adherence to treatment, concerning 'forgetfulness', 'skip', 'miss a dose', 'discontinue', 'sticking difficulties', 'feeling bothered', and 'remembering difficulties. The eight items have response choices "no" or "yes". Total TAS scores can be ranged from zero to eight and are classified into low adherence $(<\operatorname{six})$, medium adherence ( six to seven) and high adherence (eight). The scale was restructured after taking expert views of healthcare providers working in patient education and different hematology clinics in a focus group. The TAS was then piloted in a convenience sample of $10 \mathrm{TM}$ patients, with the internal consistency of 0.68 . In this study, the TAS' internal consistency was established by Cronbach's alpha of 0.76 .

\section{Data Collection Procedures}

Participants were interviewed during the hematology clinics' hours at the outpatient department. All TM patients who visited the hematology clinics for medical checkups or follow up and met the inclusion criteria were asked to be part of the study. The investigator explained the study purpose, data collection process, and confidentiality measures to participants, and those who agreed to be involved in the study were asked to sign a written consent form. Participation was voluntary and there were no benefits or intensives for the participants. Face to face interviews of participants were performed by using the assessment questionnaire for disease knowledge and treatment adherence, including sociodemographic items, in the waiting room before or after their clinic visits. The study was conducted from December 2017 to May 2018. The study questionnaire took around 10 to 15 minutes to complete. All collected data was kept in a locked drawer in the researcher's office. Only the research team had access to the collected data and all published results were de-identified to further ensure confidentiality.

\section{Data Analysis}

All statistical analyses were conducted using Statistical Package for Social Sciences version 22 (Armonk, NY; IBM Corp.). For the collected questionnaires, identification numbers have been given for counting and organizing purposes. All questions have been coded and then imported for analysis into SPSS. All categories of variables were coded with numbers (e.g. gender: one for male and two for female). Percentages, frequencies, means, and standard deviations were used to analyze sociodemographic and main study variables. Cronbach's alpha reliability testing was completed for study's instruments to determine the internal consistency. Pearson correlation coefficients were conducted to investigate the relationships between disease knowledge and adherence to treatment and sociodemographic items. Inferential statistics, and in particular, t-test and ANOVA, were also performed to examine the main study variables by their sociodemographic characteristics. The level of significance was set at 0.05 in all analyses.

\section{RESULTS}

The DKTM overall correct item score ranged from eight to 19 with an overall mean correct answer of 15.59 ( $\mathrm{SD}=2.30$ ) out of 20 items (total score if all items answered correctly). This mean score indicated that participants had a moderate level of knowledge towards TM as shown in Table 2. None of the participants achieved complete and correct response (20 or $100 \%)$. It should be underlined that $55 \%$ of the participants had a moderate level of disease knowledge, and only five percent of the participants had poor knowledge regarding TM. Based on the obtained results, there items were answered incorrectly by many participants, those related to areas of blood transfusion as treatment of TM, complications such as jaundice, and TM risk factors. Concerning TM physiology, $87 \%$ of the participants knew that TM is one of the genetic diseases and $76 \%$ of them recognized that there are three categories of TM as minor, mid, and serious. Participants had high scores in using Desferrioxamine (DFO) injections to avoid serum ferritin sedimentation (98\%), checking 
Disease Knowledge and Treatment Adherence among Adult Patients with Thalassemia: A Cross-sectional ...

Tab. 2. Descriptive statistics for disease knowledge and treatment adherence scores $(n=100)$

\begin{tabular}{|l|c|c|c|c|c|c|}
\hline \multicolumn{1}{|c|}{ Variables } & No. (\%) & Possible Range & Actual Range & M (SD) & Cronbach's Alpha & Correlation \\
\hline DKTM & $5(5)$ & & & & & \\
$\leq 10$ or $\leq 50 \%$ & $55(55)$ & $0-20$ & $8-19$ & $15.59(2.30)$ & 0.72 & \\
$11-16$ or $55-80 \%$ & $40(40)$ & & & & \\
$\geq 17$ or $\geq 85 \%$ & $85(85)$ & & & & \\
\hline TAS & $13(13)$ & $0-8$ & $3.91-8$ & $(1.83)$ & & \\
$<6$ & $2(2)$ & & & & & \\
$6-7$ & & & & & \\
8 & & & & & \\
\hline
\end{tabular}

Note: DKTM, Disease Knowledge about Thalassemia Major; (TAS), Treatment Adherence Scale; $M$, Mean; SD, standard deviation

Tab. 3. Frequency and percentage of patients correct answers in DKMT $(n=100)$

\begin{tabular}{|l|c|}
\hline \multicolumn{1}{|c|}{ Questions } & $\begin{array}{c}\text { Correct responses } \\
\text { No. (\%) }\end{array}$ \\
\hline TM is a genetic disease. & $87(87)$ \\
\hline TM is categorized into serious, mild and minor disorders. & $76(76)$ \\
\hline A TM patient needs blood transfusion. & $28(28)$ \\
\hline $\begin{array}{l}\text { Hemoglobin level for TM patients impact their physical } \\
\text { activities. }\end{array}$ & $85(85)$ \\
\hline $\begin{array}{l}\text { TM major is a result of both the parents being carriers of } \\
\text { TM. }\end{array}$ & $86(86)$ \\
\hline $\begin{array}{l}\text { The goal for injections (DF0) is to get rid of excess serum } \\
\text { ferritin. }\end{array}$ & $98(98)$ \\
\hline Accumulation of serum ferritin will cause cardiomyopathy. & $86(86)$ \\
\hline $\begin{array}{l}\text { Swelling of spleen and liver is caused by rapid destruction } \\
\text { of RBCs. }\end{array}$ & $82(82)$ \\
\hline $\begin{array}{l}\text { Once the pancreas is swollen/inflamed, it will cause } \\
\text { diabetes. }\end{array}$ & $80(80)$ \\
\hline $\begin{array}{l}\text { Doctors suggest removing spleen to avoid rapid destruction } \\
\text { of RBCs. }\end{array}$ & $90(90)$ \\
\hline $\begin{array}{l}\text { The cause of anemia is a defect in a or b chain in production } \\
\text { of Hemoglobin. }\end{array}$ & $76(76)$ \\
\hline $\begin{array}{l}\text { The hemoglobin level should be maintained above 10g/dl } \\
\text { in TM patients. }\end{array}$ & $87(87)$ \\
\hline If both parents are the TM carriers, their kids will have TM. & $58(58)$ \\
\hline Excessive accumulation of bilirubin is called jaundice. & $65(65)$ \\
\hline Serum ferritin level should be checked at times. & $90(90)$ \\
\hline $\begin{array}{l}\text { The normal range of serum ferritin levels is less than 1000 } \\
\text { mg/ml. }\end{array}$ & $85(85)$ \\
\hline $\begin{array}{l}\text { A serum ferritin level between 1000-2000 mg/ml means } \\
\text { the disease controlled well. }\end{array}$ & $87(87)$ \\
\hline $\begin{array}{l}\text { The volume of blood to be transfused depends on the } \\
\text { patient's body weight. }\end{array}$ & $93(93)$ \\
\hline The diet for TM patients should be low in iron. & $90(90)$ \\
\hline $\begin{array}{l}\text { HLA-matched bone marrow/stem cell transplantation is } \\
\text { the only possible known way to cure TM at present. }\end{array}$ & $88(88)$ \\
\hline
\end{tabular}

Note: TM, Thalassemia

ferritin periodically (90\%), removing spleen to avoid rapid destruction of blood cells (90\%), and diet should be low iron (90\%) (Table 3).

The mean score on the TAS was $3.91(\mathrm{SD}=1.83)$ on a test with a score that could range from zero to eight. The participants' scores ranged from 3.91 to eight. This mean score level indicated that participants had a poor/low level of treatment adherence as shown in Table 2. Around 13\% of the participants were found to have a medium level of treatment adherence, and only two percent had a high level of treatment adherence. The analysis of questionnaire
Tab. 4. Frequency and percentage of participants with TAS response by question $(n=100)$

\begin{tabular}{|l|c|c|}
\hline \multicolumn{1}{|c|}{ Questions } & $\begin{array}{c}\text { Yes } \\
\%\end{array}$ & $\begin{array}{c}\text { No } \\
\%\end{array}$ \\
\hline $\begin{array}{l}\text { Do you occasionally forget to take your iron chelation } \\
\text { therapy, Hydroxyurea or/and folic acid supplements? }\end{array}$ & $89 \%$ & $11 \%$ \\
\hline $\begin{array}{l}\text { Over the past month, did you take less than prescribed by } \\
\text { your physician? }\end{array}$ & $67 \%$ & $33 \%$ \\
\hline $\begin{array}{l}\text { Have you ever stopped your medicines without talking to } \\
\text { your physician? }\end{array}$ & $37 \%$ & $63 \%$ \\
\hline $\begin{array}{l}\text { Do you forget to take the medications with you when } \\
\text { you in a hurry going to work or having a busy schedule } \\
\text { (e.g. lunch invitation) or travel? }\end{array}$ & $56 \%$ & $44 \%$ \\
\hline Did you miss a tablet/injection yesterday? & $77 \%$ & $23 \%$ \\
\hline $\begin{array}{l}\text { Do you stop taking one or some of your medications when } \\
\text { you feel better or your lab tests show some improvement? }\end{array}$ & $39 \%$ & $61 \%$ \\
\hline $\begin{array}{l}\text { Have you ever felt bothered about adherence to the } \\
\text { thalassemia treatment schedule? }\end{array}$ & $58 \%$ & $42 \%$ \\
\hline $\begin{array}{l}\text { Do you have trouble remembering to take any of your } \\
\text { medications on time? }\end{array}$ & $64 \%$ & $36 \%$ \\
\hline
\end{tabular}

answers showed that $89 \%$ of the participants forgot to take their iron chelation therapy, Hydroxyurea or/and folic acid supplements, and $67 \%$ of participants did not take their medications as described by physicians. More than half of participants (58\%) reported they feel bothered about adherence to the TM treatment schedule. Also, $56 \%$ of the participants stated that they sometimes forget to take their treatment with them when having a busy schedule or going to work. Additional findings included negative response to remembering to medicines on time. Interestingly, most participants agreed that they should talk to their physicians before stopping taking their treatment (Table 4).

A significant weak positive correlation between disease knowledge and treatment adherence was found ( $\mathrm{r}=0.297, \mathrm{P}=0.041)$, which suggested a patient with more knowledge about disease adhered more to the treatment plan. There were no significant relationships or differences identified between age, gender, nationality, education, marital status, and disease knowledge or treatment adherence scores. A significant difference in TAS mean scores was found among participants with different monthly incomes $(\mathrm{F}=3.08, \mathrm{P}=0.05)$. Participants with a monthly income $\geq 10000$ SR had the highest treatment adherence mean score $(\mathrm{M}=17.11, \mathrm{SD}=2.07)$ (Table 5). 
Tab. 5. Mean scores for disease knowledge and treatment adherence by sociodemographic characteristics $(n=100)$

\begin{tabular}{|c|c|c|c|c|c|c|}
\hline \multirow{2}{*}{ Variables } & \multicolumn{3}{|c|}{ Disease Knowledge } & \multicolumn{3}{|c|}{ Treatment Adherence } \\
\hline & $M(S D)$ & $t / F$ & $\mathbf{p}$ & $M(S D)$ & $t / F$ & $\mathbf{p}$ \\
\hline \begin{tabular}{|l} 
Age \\
14 to $\geq 23$ \\
24 to $\geq 38$ \\
$<38$ \\
\end{tabular} & $\begin{array}{l}15.29(2.41) \\
16.30(1.86) \\
15.25(2.71) \\
\end{array}$ & $F=1.32$ & 0.18 & \begin{tabular}{|l|}
$3.92(1.87)$ \\
$3.97(1.94)$ \\
$3.40(1.18)$ \\
\end{tabular} & $F=0.17$ & 0.87 \\
\hline \begin{tabular}{|l|} 
Nationality \\
Saudi \\
Non-Saudi \\
\end{tabular} & $\begin{array}{l}16.86(1.96) \\
16.43(1.99) \\
\end{array}$ & $t=0.63$ & 0.92 & $\begin{array}{l}3.66(1.93) \\
4.01(1.80) \\
\end{array}$ & $\begin{array}{c}t= \\
-0.113\end{array}$ & 0.87 \\
\hline \begin{tabular}{|l} 
Gender \\
Male \\
Female \\
\end{tabular} & $\begin{array}{l}16.34(2.08) \\
16.73(1.87) \\
\end{array}$ & $t=-2.37$ & 0.051 & $\begin{array}{l}3.97(1.73) \\
3.85(1.95) \\
\end{array}$ & $t=-2.31$ & 0.87 \\
\hline $\begin{array}{l}\text { Level of education } \\
\text { Not educated } \\
\text { Elementary School } \\
\text { Intermediate School } \\
\text { High school } \\
\text { Bachelor Degree } \\
\end{array}$ & $\begin{array}{l}17.14(1.07) \\
15.67(1.56) \\
14.76(2.09) \\
16.45(2.18) \\
17.15(1.78) \\
\end{array}$ & $F=2.34$ & 0.06 & \begin{tabular}{|l|}
$3.14(2.25)$ \\
$3.54(1.45)$ \\
$3.71(1.46)$ \\
$4.29(2.15)$ \\
$3.85(1.51)$ \\
\end{tabular} & $F=1.19$ & 0.45 \\
\hline $\begin{array}{l}\text { Marital status } \\
\text { Single } \\
\text { Married } \\
\end{array}$ & $\begin{array}{l}16.51(2.09) \\
16.62(1.56) \\
\end{array}$ & $t=-446$ & 0.63 & \begin{tabular}{|l|}
$3.99(1.89)$ \\
$3.62(1.63)$ \\
\end{tabular} & $t=-488$ & 0.57 \\
\hline $\begin{array}{l}\text { Monthly income } \\
<5000 \text { SR } \\
5000-10000 \text { SR } \\
>10000 \text { SR }\end{array}$ & $\begin{array}{l}15.25(2.06) \\
16.22(1.28) \\
17.11(2.07)\end{array}$ & $F=3.61$ & 0.19 & $\begin{array}{l}3.67(1.91) \\
4.26(2.27) \\
4.88(1.61)\end{array}$ & $F=3.08$ & $0.05^{*}$ \\
\hline
\end{tabular}

\section{DISCUSSION}

This is a correlational cross-sectional study which was conducted in SA, the aim of which is to investigate the disease knowledge and treatment adherence among TM patients from a university teaching hospital in Jeddah city. There is evidence from this study that disease knowledge is positively correlated with the level of treatment adherence. Two studies support such a correlation in which a significant positive relationship was found between disease knowledge and treatment adherence among Taiwanese TM patients $(P=0.001)[15,16]$. In a study conducted in Jordan, researchers also noted that knowledgeable patients with chronic diseases are twice as probable to have moderate to high treatment adherence as their unknowledgeable counterparts [14]. Other studies, however, oppose such a positive correlation and instead find that disease knowledge and treatment adherence are negatively associated or not associated $[2,19]$. The obvious reason for the conflicting results may be because of differences in the definition and concept of knowledge and treatment adherence, the absence of theoretical definitions of these constructs, and the use of different instruments. However, treatment adherence is still considered to be a multifactorial phenomenon and failure or success of patient's adherence to treatment does not depend on a single key factor, such as disease knowledge $[2,12]$. There is a need to better understand factors, other than disease knowledge, that are significant determinants of treatment adherence and to develop appropriate strategies/interventions to reduce their impact.

The moderate level of knowledge in this study indicated that TM patients are now well educated towards disease and are eager to learn more about it, as it is the most common inherited blood disorder in SA. Resear- chers noted that having TM increases the patients' knowledge of the disease and motivates them to learn more [20]. In contrast, other studies approve the poor TM knowledge among Iranian and Indian patients and the lack of proper education to promote their understanding of TM $[21,22]$. Patients with TM in the current study had poor knowledge about TM risk factors, blood transfusion as treatment, and complications such as jaundice. In a study conducted among 172 participants in Pakistan, findings show that $40 \%$ had lower knowledge scores about TM, and around half of the participants believed that TM was an allergic reaction, one of the sexually transmitted diseases or/and a consequence of improper nutrition [23]. Contrary to these findings, some researchers reported the highest knowledge levels in the "genetic risk factor", "ways of prevention", and "adherence" domains among TM Iranian couples [24]. It is important to assess the educational needs and knowledge of TM patients to take a constructive move toward their health support. The involvement of nurses in the education of patients and improving their level of knowledge in relation to their health needs is reflected the nurses' professional and academic responsibility [25]. Also, Hinkle and Cheever have indicated that teaching the patients according to their health needs is crucial and evaluation and identification of individuals' powers are essential in their health education [26]. Strengthening of health education and improved efforts of nurses in giving practical disease knowledge would significantly enhance patients' adherence to TM long-life treatment.

Treatment adherence is a great concern for TM patients. The study findings showed that $85 \%$ of the participants had a low level of treatment adherence, and only two percent had a high level of treatment adherence. Similar to these study findings, Vardaki et al. reported that $67 \%$ of Greece MT patients had a low level of treatment adherence and $77.6 \%$ had serious health problems [18]. Another study conducted on testing adherence to treatment among 243 Iranian TM patients, researchers noted that treatment adherence was reached only in $18.2 \%$ of patients, and generally outcome was poor [27]. In line with the study findings, a previous qualitative study conducted by Zeydi et al. suggested that delay in the occurrence of complications, complicated family life, and busy working day may cause irregular following/forgetting or a discontinued of prescribed treatment by Iranian TM patients [28]. Kourorian et al. stated that the problem of poor lifelong treatment adherence is mainly exaggerated among TM patients because of many psychological and physical problems such as low self-confidence, being tired from taking long-term medications, lack of motivation for continuing the prescribed medication, and painful infusions of iron chelating agents [22]. Most patients had also poor adherence and improper attitudes toward the use of subcutaneous iron chelating agents which was linked to lack of knowledge about these new brand of drugs [22]. Based on this, developing effective adherence interventions using various educational methods for TM patients 
needs better analytic models of adherence practices. With only about two percent of the study sample having high levels of treatment adherence, more effort is also needed to identify the reasons for poor adherence among this population.

It should be emphasized that there were no significant relationships or differences in disease knowledge or treatment adherence mean scores and sociodemographic variables in this study. Only a significant difference in adherence to treatment mean scores was found among participants with different monthly incomes $(P=0.05)$. Similarly, Al-Kloub et al. noted that there was no significant difference in knowledge about TM between males and females patients $(\mathrm{X} 2=0.02, \mathrm{P}=0.80)$ [2]. Kourorian et al. also indicated that there was no statistically significant association between the disease knowledge and gender $(\mathrm{P}=0.9)$ or any sociodemographic variables in their study [22]. In contrast, knowledge about TM was found to be related to numerous factors, such as gender, level of education, marital status, and monthly income $[2,23]$. Zeydi et al. indicated that married TM patients are keener to adhere to their treatment than single patients [28]. This can be explained by that being supported by spouses can be a motivator for patients to adhering to their long-term treatment plans [28]. Also, age $(P=0.03)$ and monthly income $(P=0.04)$ were associated with treatment adherence; Jordanian patients with TM aged older than 16 years old and have poor monthly incomes were more likely to be non-adherent to treatment [2]. A review study suggested that financial constraints could impact treatment adherence because it will limit access to all healthcare aspects involving attending regular follow-up visits, seeking care when needed, getting labs, and obtaining prescribed medications [29]. Particular attention should be paid to TM patients who have poor monthly incomes as they may be at greater risk of treatment adherence problems. These findings require further investigation.

\section{Limitations}

There are several limitations to this study. The present study was conducted within a Saudi context which is different from other cultures. The use of a convenience sample in one hospital also limits the generalizability of study findings. However, this study can provide healthcare administration and nurses more insights about the importance of developing effective education programs and adherence interventions, to improve the quality of life of this population. Moreover, the cross-sectional design limits the ability to make causal relationships. Future research can more directly test the effects of disease knowledge on treatment adherence by assessing these variables longitudinally to provide stronger causal evidence. The researchers collected the data from Jeddah (city): therefore, the findings may differ when compared to the data from patients living in rural areas. A replication of this study with a large sample of TM patients in remote areas as well as within public and private hospitals is needed to compare and contrast findings. Finally, there were no relevant literature available on this topic in SA, so the direct comparison of results with existing studies was limited.1

\section{CONCLUSIONS}

This is the first study that has investigated disease knowledge and treatment adherence among adult patients with TM in SA. The findings of this study obviously revealed that there was a positive correlation between disease knowledge and treatment adherence among TM patients. Despite this, adherence to treatment is believed to be a multifactorial phenomenon, and knowledge is only one of the key factors. Solutions include evaluating health literacy, enhancing patient education, and paying attention to reasons for poor adherence among this population. A multidisciplinary approach and the development of intervention programs for patients and their families focused on promoting patient knowledge and healthy behaviors are also significant components of care, contributing to better treatment adherence. Nurses also should encourage patients to use technology to educate themselves about the disease process and complications associated with TM. Moreover, research should examine the role of the healthcare professionals, healthcare settings, and healthcare systems in promoting greater treatment adherence among TM patients in SA, and other countries and cultures.

\section{REFERENCES}

1. Cao A, Galanello R. Beta-Thalassemia. Genet Med. 2010;19(6):61-76. doi:10.1038/ gim.2016.173

2. Al-Kloub MI, Abed MA, Al khawaldeh OA, et al. Predictors of non-adherence to follow-up visits and deferasirox chelation therapy among Jordanian adolescents with thalassemia major. Pediatr Hematol Oncol. 2014;13(7):624-637. doi:10.3109/0 8880018.2014.939792.

3. Alenazi SA, Ali HW, Alharbi MG, et al. Prevalence of thalassemia and sickle cell disease in Northern border region of Saudi Arabia. Kashmir J Med Sci. 2015;1(1):3-6.

4. Memish ZA, Owaidah TM, Saeedi MY. Marked regional variations in the prevalence of sickle cell disease and beta-thalassemia in Saudi Arabia: Findings from the premarital screening and genetic counseling program. J Epidemiol Glob Health. 2011;1(1):61-68. doi:10.1016/j.jegh.2011.06.002.

5. GBD 2015 Mortality and Causes of Death Collaborators. Global, regional, and national life expectancy, all-cause mortality, and cause-specific mortality for 249 causes of death, 1980-2015: A systematic analysis for the global burden of disease study 2015. Lancet. 2016;388(10053):1459-1544. doi:https://doi.org/10.1016/ S0140-6736(16)31012-1

6. Alsaeed ES, Farhat GN, Assiri AM, et al. Distribution of hemoglobinopathy disorders in Saudi Arabia based on data from the premarital screening and genetic counseling program, 2011-2015. J Epidemiol Glob Health. 2018;7(1):S41-S47. https://doi. org/10.1016/j.jegh.2017.12.001

7. Olwi DI, Merdad LA, Ramadan EK. Thalassemia: a prevalent disease yet unknown term among college students in Saudi Arabia. J Community Genet. 2018;9(3):277282. doi:10.1007/s12687-017-0351-3.

8. Kingdom of Saudi Arabia-Ministry of Health (MOH). Response to medical advice offered by the healthy marriage program on the rise. Retrieved March 9, 2019, from http://www.moh.gov.sa/en/

9. Trachtenberg FL, Mednick L, Kwiatkowski JL, et al. Beliefs about chelation among thalassemia patients. Health Qual Life Out. 2012;10:148. doi:10.1186/1477-7525-10148.

10. Burkhart PV, Sabaté E. Adherence to long-term therapies: Evidence for action. J Nurs Scholarsh. 2003;35(3):207.

11. Borgna-Pignatti C, Rugolotto S, De Stefano P, et al. Survival and complications in patients with thalassemia major treated with transfusion and deferoxamine. Haematologica. 2004;89(10):1187-1193.

12. Lemay J, Waheedi M, Al-Sharqawi S, Bayoud T. Medication adherence in chronic illness: Do beliefs about medications play a role? Patient Prefer Adherence. 2018;12:1687-1698. doi:10.2147/PPA.S169236. 
13. PakbazZ, Treadwell M, Yamashita R, et al. Quality of life in patients with thalassemia intermediary compared to thalassemia major. Ann N Y Acad Sci. 2005;1054:457-461. doi:10.1196/annals.1345.059.

14. Awwad O, Akour A, Al-Muhaissen S, Morisky D. The influence of patients' knowledge on adherence to their chronic medications: A cross-sectional study in Jordan. Int J Clin Pharmacol Ther. 2015;37(3):504-510. doi:10.1007/s11096-015-0086-3.

15. Lee YL, Lin DT, Tsai SF. Disease knowledge and treatment adherence among patients with thalassemia major and their mothers in Taiwan. J Clin Nurs. 2009;18(4):529538. doi:10.1111/j.1365-2702.2007.02150.x.

16. Yang $H C$, Chen $Y C$, Mao HC, Lin KH. Illness knowledge, social support and self care behavior in adolescents with beta-thalassemia major. Hu Li Yan Jiu=Nursing Research 2001;9:114-124. (Original Work Published in Chinese)

17. Patton DE, Hughes $C M$, Cadogan CA, Ryan CA. Theory-based interventions to improve medication adherence in older adults prescribed polypharmacy: A systematic review. Drugs Aging. 2017;34(2):97-113. doi:10.1007/s40266-016-0426-6.

18. Vardaki MA, Philalithis AE, Vlachonokolis I. Factors associated with the attitudes and expectations of patients suffering from beta-thalassemia: A cross-sectional study. Scand J Caring Sci. 2004;18(2):177-187. doi:10.1111/j.1471-6712.2004.00267.x.

19. Nazir SU, Hassali AM, Saleem F, et al. Disease related knowledge, medication adherence and glycaemic control among patients with type 2 diabetes mellitus in Pakistan. Prim Care Diabetes. 2016;10(2):136-141. doi:10.1016/j.pcd.2015.09.004.

20. Patel AP, Parmar PH, Patel RB, et al. Factors influencing beta-thalassemia awareness in Western India. Natl J Community Med, 2016;7(3):193-197.

21. Colah R, altalia K, Gorakshakar A. Burden of thalassemia in India: The road map for control. Pediatr Hematol Oncol J. 2017;2(4):79-84. https://doi.org/10.1016/j. phoj.2017.10.002

22. Kourorian Z, Azarkeivan A, Hajibeigi B, et al. The effect of knowledge, attitude and practice on the function of thalassemia patients. Iranian Journal of Blood and Cancer. 2014;6(4):177-181.

23. Maheen H, Malik F, Siddique B, Qidwai, A. Assessing parental knowledge about thalassemia in a thalassemia center of Karachi, Pakistan. J Genet Couns. 2015; 24(6):945-951. doi:10.1007/s10897-015-9830-z.

24. Kosaryan M, Vabidshabi K, Siami $R$, et al. Knowledge, attitudes, and practices of reproductive behaviours in Iranian minor thalassemia couples. Saudi Med J. 2009;30(6):835-839.

25. Abolghasemi $\mathrm{H}$, Amid A, Zeinali $\mathrm{S}$, et al. Thalassemia in Iran: Epidemiology, prevention, and management. J Pediatr Hematol Oncolo. 2007;29(4):233-238. doi: 10.1097/MPH.0b013e3180437e02.

26. Hinkle JL, Cheever KH. Brunner and Suddarath text book of medical surgical nursing. 14th Ed. Lippincott Williams \& Wilikins: Philadelphia; Pa; 2017.

27. Pedram M, Zandian K, Keikhaie B, et al. A report on chelating therapy and patient compliance by determination of serum ferritin levels in 243 thalassemia major patients. Iran J Pediatr Society. 2010;2:65-69.

28. Zeydi AE, Moonaghi HK, Heydari A. Exploring Iranian $\beta$-Thalassemia major patients' perception of barriers and facilitators of adherence to treatment: A qualitative study. Electron Physician. 2017;9(12):6102-6110. doi:10.19082/6102.

29. Pai ALH, Ostendorf HM. Treatment adherence in adolescents and young adults affected by chronic illness during the health care transition from pediatric to adult health care: A literature review. Child Health Care. 2011;40(1):16-33.

Manuscript received: 08.05.2019

Manuscript accepted: 20.06.2019 